\title{
The "reinstatement" of credit agreements: Remarks in response to the 2014 amendment of section 129(3)-(4) of the National Credit Act
}

Reghard Brits

BCom $L L B L L D$

Postdoctoral Fellow, South African Research Chair in Property Law, University of

Stellenbosch*

\section{OPSOMMING}

Die "Herstel" van Kredietooreenkomste: Opmerkings in Reaksie op die 2014 Wysiging van Artikel 129(3)-(4) van die Nasionale Kredietwet

Voor die 2014 Wysigingswet het artikel 129(3) en (4) van die Nasionale Kredietwet voorsiening gemaak vir verbruikers om kredietooreenkomste te herstel deur alle agterstallige bedrae asook sekere kostes te betaal. Die idee was dat die skuldafdwingingsproses onderbreek word wanneer die verbruiker aan die voorgeskrewe vereistes voldoen het. Die bestaan van hierdie maatreël is belangrik om verbruikers te beskerm teen die potensieël negatiewe gevolge van die streng afdwinging van vervroegingsbedinge in kredietooreenkomste. Ook vanuit 'n konstitusionele perspektief is hierdie meganisme 'n noodsaaklike element van ons kredietreg. Subartikel (3) het die basiese reg beskryf terwyl subartikel (4) die beperkings daarop omskryf het. Ten spyte van 'n paar onsekerhede aangaande die werking van hierdie meganisme, het regspraak en akademiese kommentaar 'n algemeen werkbare uitleg van hierdie bepalings opgelewer. Die wetgewer het dit desnieteenstaande nodig geag om die subartikels te wysig. Die doel van hierdie bydrae is om sodanige wysigings te analiseer om uit te pluis wat die stand van sake is nou dat die wysigingswet in werking getree het. Dit is belangrik om te besef dat die spesifieke wysigings wat aangebring is waarskynlik nie daarop gemik is om die substansie van hierdie meganisme te verander nie. Inteendeel, die doel was waarskynlik slegs om sekere konseptuele teenstrydighede uit die weg te ruim. Die wysigings aangebring aan subartikel (3) is duidelik gemik

* This article is based on a paper presented at the University of Pretoria International Consumer Law Conference 2014 (25-27 September 2014). My gratitude to Lienne Steyn for valuable discussions as well as for reading drafts of this article. Also thank you to André van der Walt and Carolien Kriek. The South African Research Chair in Property Law (SARCPL) is funded by the South African national Department of Science and Technology, administered by the National Research Foundation and hosted by Stellenbosch University. The views expressed in this article are those of the author and should not be attributed to any of these persons or institutions.

How to cite: Brits 'The "reinstatement" of credit agreements: Remarks in response to the 2014 amendment of section 129.3) (4) of the National Credit Ace'2015 De Jure 75-9/ 
op hierdie oogmerk en is daarom onproblematies. Subartikel (4) se wysigings verg egter meer kopkrapwerk, want die letterlike bewoording mag onlogies voorkom. Die gevolgtrekking is dat die doel van artikel 129 (3) en (4) steeds is om enersyds te voorsien vir die verbruiker se reg om agterstallige bedrae op datum te bring en andersyds om die beperkinge van hierdie reg te omskryf, ten spyte van die verwarrende bewoording van veral subartikel (4)

\section{Introduction}

Ever since the National Credit Act 34 of 2005 (NCA) was enacted there has been a need to amend it to correct the many uncertainties and inconsistencies that plague the Act and that have resulted in a flood of case law and academic commentaries. ${ }^{1}$ Finally in 2013 the Department of Trade and Industry published the results of a review process ${ }^{2}$ as well as a draft amendment bill. ${ }^{3}$ After comments were considered, a bill was introduced in the National Assembly. ${ }^{4}$ A final version ${ }^{5}$ was passed by parliament in 2014 and subsequently the president assented to the National Credit Amendment Act 19 of $2014 .^{6}$ The Amendment Act came into operation on 13 March 2015 .

As part of this bigger project to amend the NCA, a decision was also made to modify section 129(3) and (4) of the Act. These provisions introduced to South African consumer law a new concept of "reinstatement" or the "right to re-instate a credit agreement". ${ }^{8}$ Due to unclear drafting, the exact requirements and limitations of this mechanism were not obvious, but its general purpose was, and remains, fairly clear. It enables consumers to rectify their default by paying the amounts in arrears on their credit agreement, along with certain charges and costs. Subject to certain qualifications, the consequence of such payment is to effectively interrupt the formal debt enforcement process. Therefore, in effect the mechanism provides a way for a consumer to

1 For general literature, see Otto \& Otto The National Credit Act Explained (2013); Kelly-Louw Consumer Credit Regulation in South Africa (2012): Scholtz et al (eds) Guide to the National Credit Act (2008 loose-leaf).

2 Draft National Credit Act Policy Review Framework 2013; see General Notice 559 in Government Gazette 36504 of 2013-05-29.

3 Draft National Credit Amendment Bill 2013; see General Notice 560 in Government Gazette 36505 of 2019-05-29.

4 B 47 - 2013; see Government Gazette 36916 of 2013-10-09.

5 B 47B - 2013.

6 See General Notice 389 in Government Gazette 37665 of 2014-05-19.

7 See Proclamation R 10 in Government Gazette 38557 of 2015-03-13.

8 Both s 13 of the Hire-Purchase Act 36 of 1942 and s 12 of the Credit Agreements Act 75 of 1980 (the NCA's predecessors) referred to the idea of reinstatement, but in both instances this was meant as a mechanism available for a certain period after cancellation of the agreement, which is different than how the NCA uses the terminology. See Otto \& Otto supra $n 1$ at 124 . On reinstatement in the previous acts, see Otto 'Right of credit receiver to reinstatement after return of goods to credit grantor' 1981 SALJ 516. 
overturn the credit provider's enforcement of his rights under the agreement's acceleration clause.

The purpose of this article is not to provide a detailed analysis of the reinstatement mechanism. Instead, the focus is on how the 2014 Amendment Act might influence the supposed right of reinstatement. ${ }^{9}$ I set out the specifics of the amendments that have been made to these subsections and, in view of the apparent purposes of the amendments, I investigate the implications for the concept of reinstatement. The Amendment Act attempts to clarify certain conceptual inconsistencies in the original subsections, but it unfortunately also introduces new uncertainties that necessitate some degree of interpretational gymnastics to make sense of the provisions.

The first draft amendment bill ${ }^{10}$ that was published in 2013, proposed the removal of section 129(3) without replacing it, while leaving section $129(4)$ as is. No explanation was given for this proposal, but in the end it was not seen through. Rather, the subsequently published Amendment Bill and the Amendment Act itself retain but amend both subsections. Unfortunately, neither the 2013 review framework ${ }^{11}$ nor the summary attached to the draft bill ${ }^{12}$ provides anything helpful regarding the legislature's intention with the amendment of these subsections. This factor complicates the task of interpreting the amendments, but one can probably assume that parliament intended to rectify some of the contradictions in the subsections. An alternative assumption is that the legislature intended to amend the substance of the right of reinstatement. However, because no explanation was given for the amendments to section 129(3) and (4), it is unlikely that the intention was to drastically amend the substance of these provisions.

After briefly considering the broader context of reinstatement, I discuss the amendments made to section 129(3) and (4). The amendment of subsection (3) is not that problematic because it is fairly clear what the legislature tried to achieve and because the substance of the consumer's right in this regard remains intact. Nothing much hangs on the fact that the terminology has changed. The only point that probably requires further clarification is the requirement that the consumer may only remedy his default before the agreement has been "cancelled", and therefore I briefly comment on this qualification. However, the most confusing aspect is the amendments to subsection (4), since it is difficult to see how a literal reading of the modified

9 This article is a follow-up to a previous article that commented on these subsections prior to their amendment; see Brits 'Purging mortgage default: Comments on the right to reinstate credit agreements in terms of the National Credit Act' 2013 Stell LR 165.

10 Draft National Credit Amendment Bill 2013. See General Notice 560 in Government Gazette 36505 of 2013-05-29.

11 Draft National Credit Act Policy Review Framework 2013. See General Notice 559 in Government Gazette 36504 of 2013-05-29.

12 B 47 - 2013. See Government Gazette 36916 of 2013-10-09. 
subsection could reflect what must have been the legislature's true intention. Consequently, an attempt is made at explaining how one should approach the interpretation of this subsection in view of the broader scheme of the reinstatement concept.

Taken as a coherent whole, the conclusion is that section 129(3) and (4) still involves a reinstatement mechanism (or a right to "remedy a default") for the consumer. Subsection (3) establishes the right and subsection (4) sets out the limitations of the right - even though, especially with regard to subsection (4), a degree of interpretational creativity is needed for this consumer protection mechanism to make sense.

\section{General Context: Resolving Disputes to Avoid Debt Enforcement}

Before considering how section 129(3) and (4) was amended, it is useful to place the reinstatement mechanism in context by taking a step back. In order to understand the idea behind reinstatement it is necessary to consider how it fits into the broader scheme of the Act and how it correlates to the Act's policy choice in favour of extra-judicial dispute resolution. Moreover, it is necessary to keep in mind the indispensable function that reinstatement fulfils in South African consumer law. A more normative question that must also be asked in this context is: What reinstatement-type mechanism does South African consumer law need for it to be fair, functional and - above all - in line with the country's constitutional norms?

It is apparent that the NCA encourages the resolution of disputes between credit providers and consumers so that, if possible, debt enforcement through litigation should be avoided and to ensure that the credit transaction can instead be seen through to its natural conclusion. In most instances this is better for all parties concerned. In a manifestation of this policy choice, the Act requires that the credit provider must first send a notice of default to the consumer, containing suggestions and giving him an opportunity to resolve the dispute. ${ }^{13} \mathrm{~A}$ debtor who rectifies his breach of contract in response to this notification provides a prime example of a dispute being resolved. ${ }^{14}$ This preference for solving the dispute is confirmed by the fact that, if there is no default, the credit provider has no locus standi to sue the consumer, ${ }^{15}$ and the

13 S 129(1)(a) of the NCA.

14 See the comments in Kubyana v Standard Bank of South Africa Ltd 20143 SA 56 (CC) par 22; Sebola v Standard Bank of South Africa Ltd 20125 SA 142 (CC) parr 46-49; Imperial Bank v Kubheka (28713/08) 2010 (GPPHC) 3 (201002-04) parr 55 \& 58; Firstrand Bank Ltd v Olivier 20093 SA 353 (SE) par 18. For the purposes of the NCA, see s 3 of the Act.

15 S 130(1) states that "a credit provider may approach the court for an order to enforce a credit agreement only if, at that time, the consumer is in default ...". 
court has no jurisdiction to hear the matter. ${ }^{16}$ In general one can hardly quibble about the logic of this arrangement. The alternative could have inequitable results, which is also the reason why, even before the NCA, the strict enforcement of cancellation and acceleration clauses was limited under certain circumstances. ${ }^{17}$

However, what about instances where the consumer rectifies his default after the creditor had approached the court to commence enforcement proceedings? This is where the concept of reinstatement as contemplated in section 129(3) and (4) becomes relevant. Here we are dealing with the situation where, because the consumer was in default when the creditor approached the court, the creditor has locus standi to sue and the court has jurisdiction to hear the matter. However, if at some point during the enforcement process, the consumer complies with the requirements of section 129(3) and (4), the agreement will be "reinstated" and the enforcement process will be overturned. Generally speaking, the structure of the reinstatement mechanism involves two aspects: The first part is subsection (3), which establishes the consumer's right to reinstate the agreement and stipulates for certain requirements, such as the relevant amounts payable. The second part is subsection (4), which delineates the limits of the right, namely the stages in the process after which reinstatement is no longer possible.

All-out debt enforcement can have some obvious detrimental impacts on consumers' social and economic well-being, but in many cases these will be justifiable, for example to give effect to credit providers' legitimate interests and to honour contracts. However, the effects of debt enforcement may sometimes go so far that it not only has disproportionate socio-economic effects on the consumer concerned but also compromises the integrity of the system as a whole. There is no doubt that the efficient enforcement of creditors' rights is important for society and the economy overall. However, an over-emphasis on creditors' interests might create benefits for society, or a small portion thereof, that are not justified in view of the broader prejudice caused at the same time. Indeed, the whole purpose of the NCA is to rectify and prevent imbalances in the credit market. ${ }^{18}$ The Act clearly recognises the negative impact that over-indebtedness, reckless lending and unregulated debt enforcement, amongst others, can have on society. As explained earlier, if debt enforcement can at all be prevented or overturned so that the transaction can follow its normal course, this is the preferable choice instead of the financial and social costs that inevitably accompany debt enforcement. Reinstatement as a consumer protection mechanism can therefore play a contributing role in avoiding the

$16 \mathrm{~S}$ 130(3)(c)(ii)(dd) provides that, if the consumer has brought the payments contemplated in the notice of default up to date before the creditor approaches a court, the court may not even hear the matter.

17 See for example s 13 of the repealed Hire-Purchase Act 36 of 1942; s 12 of the repealed Credit Agreements Act 75 of 1980; and in general Otto supra $n$ 8.

$18 \mathrm{~S} 3$ of the NCA. 
unnecessary and costly socio-economic effects that the strict enforcement of acceleration clauses might otherwise have.

A good example of the importance of reinstatement, is where repayment of the debt is secured by a mortgage bond over residential property. The value of reinstatement was articulated in Dwenga $v$ First Rand Bank Ltd, where the court explained that reinstatement is "the beacon ... that keeps the hope alive" for consumers who desire to "weather the hard times and keep their homes, and dignity". ${ }^{19}$ Therefore, the potential benefit for home-owning consumers is evident. If they can pay the amounts outstanding on their mortgage loan (along with the costs and charges), this should prevent mortgage foreclosure from going ahead. Ideally they should have the opportunity to make such payments and thereby reinstate the mortgage agreement until the moment that the judgment against them has been executed - thus until the property is sold at a public auction. Under the original section 129(3) and (4), this is how the right of reinstatement was generally interpreted, ${ }^{20}$ and it is unlikely that the 2014 amendments were intended to substantively restrict the scope of application of these subsections.

The importance of reinstatement in the housing context is also illustrated by the impact of the Constitution on the law of civil procedure. Section 26(1) of the Constitution ${ }^{21}$ provides that everyone has the right to have access to adequate housing. Without going into any details, the general understanding is that a forced sale of, or an eviction from, a home in principle involves a violation of the negative duty not to limit a person's existing access to adequate housing. ${ }^{22}$ A sale in execution of a primary residence is therefore not permitted to have an effect on the homeowner that is unjustifiable in terms of section 36(1) of the Constitution, which - again, without going into any details - entails a strict proportionality test. ${ }^{23}$ If the effect of the sale in execution on the homeowner would be disproportionately harsh in comparison to the purpose of the sale, such sale would not be allowable. In other words, if the creditor's rights under the acceleration and foreclosure clauses are

19 Dwenga $v$ First Rand Bank Ltd (EL 298/11, ECD 298/11) 2011 (ECELLC) 13 (2011-11-29) par 35 n 36

20 See particularly Firstrand Bank Limited v Nkata (213/2014) 2015 (SCA) 44 (2015-03-26) parr 23, 27, 34, 38-39, $41 \&$ \& 44; Nkata $v$ Firstrand Bank Limited 20142 SA 412 (WCC) parr 51-53; Nedbank Ltd v Fraser 20114 SA 363 (GSJ) parr 40-41; and further Brits supra n 9 at 175-178; Coetzee 'Voluntary surrender, repossession and reinstatement in terms of the National Credit Act 34 of 2005' 2010 THRHR 569581

21 Constitution of the Republic of South Africa, 1996

22 The most important cases on this point are Jaftha $v$ Schoeman and Others, Van Rooyen v Stoltz 20052 SA 140 (CC); Gundwana v Steko Development 20113 SA 608 (CC)

23 For a more detailed analysis of how ss 26(1) \& 36(1) operate in the mortgage context, see Brits \& Van der Walt 'Application of the housing clause during mortgage foreclosure: a subsidiarity approach to the role of the National Credit Act (part 1)' 2013 TSAR 288 290-294 and the sources cited there. 
strictly enforced despite the arrears being paid up, which is the traditional common law position, ${ }^{24}$ the result might often be disproportionately harsh for the consumer. The consumer would lose his home despite the fact that other, less invasive, ways were available (and indeed pursued) to honour the creditor's interests. In all likelihood, this outcome would not satisfy the test in section 36(1) of the Constitution.

A comparable example is ABSA Bank Ltd $v$ Ntsane, ${ }^{25}$ where the court relied on the principles in section 26 of the Constitution and refused to allow the creditor to accelerate repayment of the full capital debt of R62 042.43, because the actual amount outstanding was only R18.46. If foreclosure and a sale in execution were held to be unacceptable under these circumstances, how much more unacceptable would it be to allow foreclosure if the arrears are completely purged? The NCA was not yet in force when Ntsane was decided but, as the court in Nedbank Ltd v Fraser ${ }^{26}$ subsequently explained, reliance on the right of reinstatement would have been the perfect solution in a case like Ntsane. ${ }^{27}$ The point is that there may be situations where the opportunity for a debtor to make use of the reinstatement mechanism is the ideal (and perhaps only) way in which an otherwise unjustifiable sale in execution can be avoided. Therefore, a generously-interpreted right of reinstatement is arguably a necessity in order for unconstitutional sales in execution to be avoided.

Reinstatement is also a reasonable compromise because it does not deny the creditors' rights, but merely limits them to achieve the important purpose of avoiding debt enforcement, and its social consequences, if the debtor's default is rectified in time. Granted, reinstatement may cause inconvenience to a credit provider who is in the process of enforcement proceedings when the consumer pays up and reinstates the agreement, but this is compensated for by the charges and costs that the consumer must pay. Also, the benefits of protecting a home far outweigh the administrative inconvenience experienced by the creditor. If the creditor receives the outstanding amounts plus charges and costs, there is no reason why it would want to continue enforcing the agreement or go ahead with a sale of the property. ${ }^{28}$

The purpose of the foregoing discussion is to emphasise the importance of having a clearly defined mechanism as far as the rectifying of default is concerned. It is therefore important for the NCA to include a

24 See for example Boland Bank Ltd v Pienaar 19883 SA 618 (A) (mortgage creditor can refuse late payment); and also Brits supra $\mathrm{n} 9$ at 167.

25 ABSA Bank Ltd v Ntsane 20073 SA 554 (T).

26 Supra n 20 par 39.

27 Regarding the Ntsane and Fraser cases, see further Brits \& Van der Walt supra $\mathrm{n} 23$ at 298-305.

28 For present purposes I assume that these costs and charges, as currently stipulated for in the Act (see s 129(3) read with s 1 sv "default administration charge", "collection costs", s 101(1)(f)-(g)), are sufficient to compensate the credit provider for expenses incurred prior to reinstatement. If this proves not to be the case, I am open for a reconsideration of how these amounts should be calculated. 
mechanism that avoids instances where debt enforcement could have an unconstitutional result. Without expanding on this perspective any further, the point is simply that it is essential to understand that section 129(3) and (4) must be interpreted with not only the exact wording, but also the broader constitutional and socio-economic context in mind.

Reinstatement of credit agreements is an important part of the current consumer law regime, and therefore it is unfortunate that the legislature seems incapable of describing it in exact terms. However, I foresee that it is possible to interpret section 129(3) and (4) in a way that gives effect to constitutional norms. Below I explain that, even though the changes made to subsection (3) are not perfect, they are not fatally problematic, since the basic idea remains intact and because some conceptual contradictions are removed. However, the amendments to subsection (4) are confusing because they disturb the structural relationship between subsections (3) and (4). Nevertheless, with some effort one can probably arrive at a sensible interpretation of this subsection as well.

\section{The Amendment of Section 129(3)}

As stated above, the general idea of section 129(3), is to establish a right for consumers to reinstate credit agreements by paying the stipulated amounts. The original subsection (3) provided as follows:

(3) Subject to subsection (4), a consumer may -

(a) at any time before the credit provider has cancelled the agreement reinstate a credit agreement that is in default by paying to the credit provider all amounts that are overdue, together with the credit provider's permitted default charges and reasonable costs of enforcing the agreement up to the time of reinstatement; and

(b) after complying with paragraph (a), may resume possession of any property that had been repossessed by the credit provider pursuant to an attachment order.

The modified subsection (3) provides as follows:

(3) Subject to subsection (4), a consumer may at any time before the credit provider has cancelled the agreement, remedy a default in such credit agreement by paying to the credit provider all amounts that are overdue, together with the credit provider's prescribed default administration charges and reasonable costs of enforcing the agreement up to the time the default was remedied.

What has changed textually? There are no longer two paragraphs (a) and (b), but only one subsection. The content of the original paragraph (a) is substantially repeated but with the crucial difference that the phrase "re-instate a credit agreement" is deleted and replaced with the 
consumer's right to "remedy a default under such credit agreement". 29 The content of paragraph (b) is completely removed.

Section 129(3) no longer uses the terms "re-instate" and "reinstatement", but provides that the consumer may "remedy" his default at any time before the creditor cancels the agreement. It is debatable whether the term "reinstatement" can or should therefore still be used to describe this mechanism, since references to the term were removed from section 129(3). However, as explained below, the term still appears in section 129(4) and hence, for lack of a better word, it is generally still useful to employ the term to describe this feature of the NCA.

There are probably two theories for explaining the change in terminology. The first is that the idea of reinstatement, perhaps as previously understood, is not what the legislature has in mind for the future. Accordingly, the legislature possibly wanted to bring about changes to the substance of the consumer's rights in this regard. However, there is no express indication of what this substantive modification is supposed to be. Therefore, the more likely explanation for the change in terminology is that the legislature simply wanted to remove the conceptual contradictions in the original subsection (3)(a) as well as those between subsection 3(a) and (b).

The original section 129(3)(a) provided that, if the debtor pays all the amounts that are overdue 30 plus certain costs and charges, the credit agreement would be reinstated but only if this was done before the creditor had "cancelled" the agreement. Paragraph (b) stated that, after such amounts had been paid, the debtor was entitled to "resume possession of any property that had been repossessed by the credit provider pursuant to an attachment order". Otto criticised the conceptual contradictions in this subsection as follows:

It escapes my mind how, first, an agreement which has not been cancelled can be reinstated. Secondly, it is not clear how a person can resume possession of a thing which has been repossessed pursuant to an attachment order, if the agreement was not cancelled to justify such an attachment order in the first place. ${ }^{31}$

A partial solution to this inconsistency was presented recently in Nkata $v$ Firstrand Bank Limited, ${ }^{32}$ where the Western Cape High Court

29 The reference to "reinstatement" at the end of the sentence is similarly replaced.

30 This amount does not refer to the full outstanding capital debt, but only to the amounts actually overdue: see Firstrand Bank Limited $v$ Nkata supra n 20 at parr 12 \& 24; Nkata $v$ Firstrand Bank Limited supra $n 20$ at parr 36-38; Nedbank Ltd v Fraser supra n 20 at par 41; and also Brits supra n 9 at 179 \& 181-182.

31 Otto The National Credit Act Explained (2006) 98, similarly repeated in Otto $\&$ Otto The National Credit Act Explained (2010) 117; Otto \& Otto supra $n 1$ at 125.

32 Nkata $v$ Firstrand Bank Limited supra n 20 
explained that there is a conceptual distinction between the cancellation of an agreement and specific performance of an acceleration clause:

Where an agreement is terminated by the credit provider because of the consumer's breach, the contract is terminated by the act of the credit provider (provided he has complied with the procedures laid down in the Act). The remedies then available to the credit provider are those provided by law where a contract has been terminated because of breach. Where the credit provider invokes an acceleration clause, the contract remains in force and the consumer is obliged to make specific performance of the accelerated indebtedness. If the consumer pays the accelerated indebtedness, the contract will be terminated not by the act of the credit provider but through performance by the consumer. ${ }^{33}$

Essentially therefore, the court held that "the enforcement of an acceleration clause does not in law constitute a cancellation of the agreement". ${ }^{34}$ Generally speaking the distinction between cancellation and specific performance is doctrinally sound, and it is probably the most plausible way to make sense of the reinstatement mechanism as a whole. The benefit of this logic is that the before-cancelled qualification is not a major limitation of the consumer's rights. Consequently, it is reasonably clear that section 129(3) deals with the situation where the credit provider is in the process of enforcing the acceleration clause in the credit agreement. It does not deal with any situation after the agreement has been cancelled. However, at any time during the enforcement process, but before cancellation, it is still open to the consumer to pay the outstanding amounts and thereby overturn the creditor's decision to enforce the acceleration clause.

Despite the way in which the High Court in Nkata interpreted and applied section 129(3), it was still necessary to clean up the terminological confusion surrounding the idea of reinstating an agreement that has not yet been cancelled, as well as the implication that property might have been attached prior to cancellation. As Otto pointed out in the passage quoted above, it is nonsensical to refer to the reinstatement of an agreement that is still in force and which has not yet been cancelled. Presumably, this is why the legislature chose to remove references to the notion of reinstatement from subsection (3) and replaced it with the more neutral idea of "remedy a default". This amendment is helpful to maintain terminological logic but it is important to consider that this change in terminology probably does not impact the basic concept of what the consumer's rights in this regard entail.

Similarly, the striking out of paragraph (b) might have the advantage of removing the other contradiction pointed out by Otto, namely the idea that property could be repossessed before cancellation. Yet, this removal might have broader consequences than merely getting rid of a contradiction, since it may imply that, even if he remedies his default, the

33 Idem par 39

34 Ibid. 
consumer is not entitled to be placed back in possession of property that has been repossessed. This might indicate the legislature's intention that the opportunity to remedy the default is no longer available at a stage after the property has been repossessed. The legislature, however, probably only intended to rid the subsection of the contradictions pointed out by Otto, and one should not assume any intention to substantively amend the consumer's rights as such. Hence, one should not read more into the removal of paragraph (b) than the mere purpose to rid the subsection of conceptual contradictions. In any event, the removal of paragraph (b) does not create a serious lacuna, because the operation of section 129(4) probably still covers instances where the consumer remedies the default after repossession or attachment of the property.

In summation, the amended section 129(3) still permits consumers who have fallen into arrears to remedy their default by paying the relevant outstanding amounts and prescribed charges and costs. However, this mechanism is only available before the credit provider has cancelled the agreement. This cancellation does not refer to the situation where the creditor is in the process of enforcing the acceleration clause. Therefore, enforcement of the acceleration clause does not prevent the consumer from remedying his default. If the consumer complies with section 129(3) and none of the restrictions in section 129(4) apply, the implied legal consequence is that the enforcement process is interrupted and nullified. Although paragraph (b) has been removed, it is still obvious that, subject to subsection (4), any attached or repossessed property must be returned to the consumer in instances where debt enforcement is not going ahead.

Before continuing to a discussion of the amendments to section $129(4)$, it is necessary to briefly consider the before-cancelled qualification in section 129(3), since it may not be that obvious when a credit agreement will be regarded as having been "cancelled" for purposes of the NCA. As stated above, the court in Nkata held that "cancelled" in this regard, does not refer to the specific enforcement of an acceleration clause. ${ }^{35}$ Therefore, the before-cancelled qualification does not place a significant limitation on the consumer's right to remedy the default, since cancellation in this sense hardly ever plays a role in the credit context.

The general implication of the explanation given in Nkata is that the term "cancelled" probably refers to the normal concept in contract law in terms of which one party (the creditor) chooses to terminate the agreement as a result of the other party's (the debtor's) breach of contract. ${ }^{36}$ However, in view of the structure and purposes of the NCA,

35 Ibid

36 See Van der Merwe, Van Huyssteen, Reinecke \& Lubbe Contract: General Principles (2012) 343-344; Christie \& Bradfield Christie's The Law of Contract in South Africa (2011) 561-565; and also Brits supra n 9 at 174. 
it is important to consider that, even when the creditor cancels the agreement (instead of enforcing the acceleration clause), the requirements and procedures of sections 123,129 and 130 must still be complied with to enforce the cancellation. As the court in Nkata acknowledged, ${ }^{37}$ regardless of whether the creditor cancels a credit agreement or enforces the acceleration clause, in both instances he must follow the procedures set out in the Act. This approach must necessarily be correct, because it is inconceivable that the legislature would have intended a situation where a creditor can avoid following the procedures in the Act simply by cancelling instead of enforcing the agreement. ${ }^{38}$

Regardless of how the concepts of cancellation, termination and enforcement relate to and differ from each other - which is a broader controversy that goes beyond the scope of the present problem - it is safe to conclude that the only way to cancel, terminate or enforce the agreement is through debt enforcement proceedings in compliance with sections 123, 129 and 130 of the NCA. After this process has been concluded, the agreement will be regarded as fully cancelled, terminated or enforced. ${ }^{39}$ Therefore, the consumer may remedy his default up until the moment that the creditor has cancelled the agreement by complying with the requirements, and following the procedures set out in the Act.

\section{The Amendment of Section 129(4)}

In order to ensure certainty for all parties involved, it is important to provide for a point in the process until which the consumer can still remedy his default. The original section 129(4) fulfilled this function by delineating the limitations of the consumer's right of reinstatement, as is also indicated by the fact that subsection (3) is made subject to subsection (4). The original subsection provided as follows:

(4) A consumer may not re-instate a credit agreement after -

(a) the sale of any property pursuant to -

(i) an attachment order; or

(ii) surrender of property in terms of section 127;

(b) the execution of any other court order enforcing that agreement; or

(c) the termination thereof in accordance with section 123.

Therefore, reinstatement is prohibited only after the attached or surrendered property has been sold; a court order that enforces the

$37 \quad$ Nkata $v$ Firstrand Bank Limited supra n 20 at par 39

38 Despite the position taken by Eiselen 'National Credit Act 34 of 2005: The confusion continues' 2012 THRHR 389 394-398, and despite some indications in the cases that the author discusses, I am not convinced that extra-judicial cancellation of a credit agreement by a credit provider (that is, without following the prescribed procedure) is permitted by the NCA. However, for present purposes I do not investigate this point further. See further Brits supra $\mathrm{n} 9$ at 172-175. 
agreement has been executed; or the agreement has been terminated in terms of section 123. ${ }^{40}$ The original subsection (4) was not that problematic, although there were some inconsistencies between the events listed in the subparagraphs. ${ }^{41}$ Case law confirmed that reinstatement would at least have to be possible until the point that judgment has been granted, ${ }^{42}$ and perhaps even until after the property has been sold, ${ }^{43}$ but not after ownership has been transferred. ${ }^{44}$ Although reinstatement after sale in execution seems unlikely and impractical, ${ }^{45}$ the courts' interpretation of section $129(2)$ and (3) at least supports the argument that reinstatement is possible until the judicial enforcement process is complete. ${ }^{46}$

Why the legislature therefore deemed it necessary to amend the subsection in the way it did, is not clear. As indicated above, the initial plan was to leave subsection (4) unchanged, but within a relatively short period the decision was made to amend it instead and no explanation was given for this. This quick and drastic, yet unexplained, amendment leads me to speculate whether there was any rational purpose behind this move. The amendments to subsection (4) do not seem to be aimed at clarifying any particular uncertainties; in fact, the result is that it creates more confusion than before. The modified version of subsection (4) provides as follows:

(4) A credit provider may not re-instate or revive a credit agreement after -

(a) the sale of any property pursuant to -

(i) an attachment order; or

(ii) surrender of property in terms of section 127;

(b) the execution of any other court order enforcing that agreement; or

(c) the termination thereof in accordance with section 123.

What has changed textually? The original subsection (4) delineated the limits of the consumer's right to reinstate the credit agreement. The new version of the subsection appears to turn this around by replacing the reference to "consumer" with "credit provider". The term "re-instate" is

40 S 129(4)(a)-(c) of the NCA. See Firstrand Bank Limited $v$ Nkata supra $\mathrm{n} 20$ at parr 23, 27, 34, 38-39, $41 \& 44 ;$ Nkata $v$ Firstrand Bank Limited supra $n 20$ at parr 51-53; Nedbank Ltd $v$ Fraser supra n 20 at parr 40-41; and further Brits supra $\mathrm{n} 9$ at 175-178; Coetzee 'Voluntary surrender, repossession and reinstatement in terms of the National Credit Act 34 of 20052010 THRHR 569581.

41 See Brits supra $\mathrm{n} 9$ at 175-178.

42 Dwenga v First Rand Bank Ltd supra n 19 at par 35 n 36.

43 Nkata $v$ Firstrand Bank Limited supra n 20 at parr 51-53.

44 Nedbank Ltd $v$ Fraser supra $\mathrm{n} 20$ at parr 40-41. See also ABSA Bank Ltd $v$ Morrison 20135 SA 199 (GSJ) parr $24 \& 26$.

45 Brits supra $\mathrm{n} 9$ at 176-178; Botha 'A home owner's automatic mechanism for taking the sting out of default judgment' 2014 March Property Law Digest 2 .

46 Firstrand Bank Limited $v$ Nkata supra n 20 at parr 23, 27, 34, 38-39, 41 \& 44; Nkata $v$ Firstrand Bank Limited supra $n 20$ at par 55. 
retained but "or revive" is added. This is now the only place in the Act that makes express reference to the notion of reinstating a credit agreement, as the term is removed from subsection (3). This is also the only mention of reviving a credit agreement. A surface reading of the subsection creates the impression that, unlike the previous right of reinstatement, the consumer's right to "remedy a default" is not qualified by the events listed in section 129(4), since this subsection now expressly refers to the credit provider's - not the consumer's - rights.

What is one to make of the replacement of "consumer" with "credit provider"? If taken literally, the amendments to subsection (4) imply the introduction of a new concept, namely the credit provider's, as opposed to the consumer's, right to "re-instate or revive" a credit agreement, which is limited by the events listed in paragraphs (a) to (c). There is no other reference to something like this in the Act and there is, to my knowledge, no reason to think that such a right is necessary or had ever been advocated for. It is not clear why "or revive" had to be added to the subsection either. Is revival somehow different than reinstatement?

Consequently, subsection (4) ostensibly no longer has anything to do with whatever the consumer's right under subsection (3) is intended to be, since these now clearly involve two different rights attributed to two different parties. The result may be that subsection (4) can no longer be used to interpret the confines of the right stipulated in subsection (3). However, this state of affairs would be strange because subsection (3) is still expressly made subject to subsection (4). How can the consumer's right to "remedy a default" prior to cancellation be made subject to the limitations placed on the credit provider's ostensible right to "re-instate or revive" a credit agreement?

A right for the credit provider to "re-instate or revive" a credit agreement hardly fits into the Act as a whole, but it is especially out of place in section 129. Firstly, why would the creditor ever want to reinstate a credit agreement? Secondly, forcing reinstatement on a consumer is at odds with the purposes of the Act and would be inequitable. One explanation might be that the legislature wants to afford the creditor the choice whether to accept the debtor's payment of arrears, hence reinstatement, after debt enforcement proceedings have commenced. Therefore, whether the agreement is reinstated is in the creditor's discretion. However, this does not make sense either. Firstly, if both parties want to reinstate, there is no dispute and hence no need for a specific statutory measure, since they could consensually arrange the matter. Secondly, if the legislature wanted to afford the creditor such a discretion, this could have been achieved in a much simpler and clearer manner

It may consequently be that the amended section 129(4) gives the discretion to "reinstate or revive" the credit agreement after cancellation to the credit provider alone, but that he can elect to do so only until any of the events listed in paragraphs (a) to (c) takes place. Even if the 
consumer pays all outstanding amounts, he is at the mercy of the credit provider who can elect whether or not to allow reinstatement. This would be a bizarre arrangement for which there is no principled reason. It also seems to contradict the overall purposes of the Act and it may even discourage the creditor's co-operation in extra-judicial dispute resolution.

Taken literally, therefore, the amended section 129(4) would have no practical meaning as far as the consumer's rights are concerned. This is a shame because the original version was a useful addition to the stipulation for the consumer's right of reinstatement, since it stipulated the confines of the right. The prospect that section 129(4) is no longer relevant will cause problems, because there is now nothing to indicate until which point in the process the remedy of default can take place. It is hard to believe that this repercussion was intended.

The fact that subsection (3) is still expressly made subject to subsection (4) might give an indication of how the two could fit together and what the function of subsection (4) is meant to be, notwithstanding its odd wording. In all likelihood the intention is still that subsection (4) should indicate the confines of the reinstatement mechanism. Logically, this makes sense but, if so, it is achieved through extremely poor drafting. To make practical sense of section 129(3) and (4) - as a coherent whole regarding the right of "reinstatement" - one is left with no other option than to stretch the wording of subsection (4).

Hence, there are two options when interpreting the amendment of section 129(4): The first option is that the legislature replaced "consumer" with "credit provider" so as to indicate that the reinstatement mechanism should be in the hands of the credit provider and not the consumer. This implies that subsection (4) no longer serves to indicate the limits of the consumer's right to remedy the default, but that it refers to some separate, albeit unexplainable, right of the credit provider. As I explain above, this approach is illogical and therefore it is difficult to accept that this was the legislature's intention.

The second option is to assume that the amendments made to section 129(4) should not be taken literally and, for all practical purposes, might have to be ignored. A strong indication of this possibility is the fact that the first draft amendment bill proposed no amendments to this subsection, and therefore the final version is probably the result of lastminute drafting confusion. Since the legislature also provided no explanation for the amendment, one must assume that it was never the intention to bring about the kind of substantive change that the literal wording of the modified subsection appears to indicate.

It is regrettable that the legislature leaves one with little choice but to disregard the actual wording of the NCA on this point, because the alternative would simply be too nonsensical. The bizarre reality is that one is compelled to interpret section 129(4) as if it has not been amended at all. Therefore, one must simply read section 129(4) as still providing for the limitations upon the consumer's right of "reinstatement" (or to 
"remedy a default"), regardless of the fact that the subsection now literally refers to the limitations on the credit provider's ostensible ability to reinstate or revive the agreement. What the legislature probably intended to do with the amendments to section 129(4) was to emphasise that the credit provider must allow reinstatement if the consumer remedies his default prior to any of the events listed in the subsection. After these events, the credit provider may (or must?) refuse to accept late payment. Not allowing reinstatement after property has been sold generally makes sense, because the alternative would create too much uncertainty for purchasers of property at sales in execution.

The aspect of section 129(4) that could have benefitted from the amendment process is clarification regarding the listed events after which reinstatement is no longer possible. This is the only issue in the subsection that has led to some uncertainty, since not all the cases were in agreement as to the latest point in the process until which the consumer can still rectify his default. ${ }^{47}$ As I have pointed out, the general idea seems to be that reinstatement should be permissible until the moment that the agreement has been fully enforced or cancelled, which moment depends on the circumstances of the case. If property is involved, it would be when a sale in execution takes place; when no property is involved, it would be when judgment is granted. However, the wording of the subsection could have been clearer in this respect. Therefore, if anything, this is the issue that the legislature should have given attention to in subsection (4), instead of the unnecessary, and confusing, replacement of terminology that was opted for.

\section{Conclusion}

The regrettable reality is that the 2014 Amendment Act was a missed opportunity to simplify the right of reinstatement, its requirements and qualifications. By now we are accustomed to the unique way in which the NCA must be interpreted to make sense of matters. One is therefore compelled to squeeze the wording of the section 129(3) and especially subsection (4) into the general understanding of what a practicable and fair reinstatement mechanism should look like in view of the Act's purposes as well as the constitutional context.

The point of departure when interpreting the subsections is the Act's clear policy preference for dispute resolution and the avoidance of expensive litigation. The assumption is that, if at all possible, credit agreements should not be cancelled, terminated or enforced, but they should instead be seen through to their natural conclusion. Consequently, it is imperative to find creative ways to resolve disputes

47 See for example Dwenga $v$ First Rand Bank Ltd supra n 19 at par 35 n 36 (until judgment is granted); Nkata $v$ Firstrand Bank Limited supra $\mathrm{n} 20$ at parr 51-53 (until the property is sold); Nedbank Ltd $v$ Fraser supra n 20 at parr 40-41 (until the sold property has been transferred). See further Brits supra $\mathrm{n} 9$ at $176-178$. 
by rectifying breaches of contract. The Act entails various such options, a notable example being the debt review process and its potential consequence of debt rearrangement. In the present context the possibility of reinstatement should be seen as being aimed at achieving the same purpose, and therefore the remedying of default should be encouraged $^{48}$ and available as an option for as late in the enforcement process as possible. This broad interpretation of the reinstatement mechanism is supported by the undeniable value it can have in avoiding unjustifiable limitations of constitutional rights, as is particularly evident if a debtor's home is at stake.

Taken on its own, the modified section 129(3) is not that problematic. The new version at least maintains a right for the consumer to remedy his default before the agreement is cancelled. The before-cancelled qualification is not a problem, since it does not preclude reinstatement during the process of specifically enforcing the acceleration clause. Therefore, as long as the creditor does not cancel the agreement (in the strict sense), the consumer is free to remedy his default by paying the prescribed amounts. As far as it goes, this arrangement makes sense.

The true confusion comes in when the amended section 129(4) is added to the picture. Previously it indicated the points in the debt enforcement process after which the consumer may not reinstate the agreement any longer. Now it refers to points in the process after which the credit provider may no longer reinstate the agreement. Listing these limitations from the credit provider's instead of the consumer's perspective is strange and a literal reading makes little sense. Notwithstanding, it is necessary that there should be some indication of the point until which the right established in section 129(3) is no longer exercisable, and one could assume that, despite poor drafting, this is still the purpose of section 129(4). The notion that the credit provider now has some sort of right of reinstatement is incomprehensible and hence one must assume that the legislature merely failed to express its true intention in coherent language.

In conclusion, it is a pity that one must go through such mental gymnastics and creative interpretation to come to a clear understanding of what the NCA's reinstatement mechanism is all about. The Amendment Act was meant to clarify matters, and it is disappointing that the result is continued confusion. Hopefully the amended section 129(3) and (4) will not cause problems in practice, although one can expect that it will not be long before a court will be faced with the task of explaining how these provisions should apply. Perhaps this contribution will provide the courts with some assistance.

48 See for example Nedbank Ltd $v$ Fraser supra n 20 at par 42, where the court advised that, when an execution order is granted against residential property, the debtor should be informed of his right to reinstate the agreement. 